Zeszyty Naukowe Szkoły Głównej Gospodarstwa Wiejskiego w Warszawie

Problemy Rolnictwa Światowego tom 18 (XXXIII), zeszyt 2, 2018: 238-248

DOI: $10.22630 /$ PRS.2018.18.2.51

Monika Radzymińska $^{1}$, Dominika Jakubowska ${ }^{2}$, Ewa Siemianowska ${ }^{3}$

Uniwersytet Warmińsko-Mazurki w Olsztynie

\title{
Postawy młodych konsumentów wobec ekologicznych produktów piekarniczych i cukierniczych - studium przypadku
}

\section{Attitudes of Young Consumers Towards Ecological Bakery and Confectionery Food Products - a Case Study}

\begin{abstract}
Synopsis. W pracy przedstawiono wyniki badań dotyczące postaw młodych konsumentów wobec nowo zaprojektowanych, niedostępnych w sprzedaży ekologicznych produktów piekarniczych (10 wariantów rogali) oraz cukierniczych (10 wariantów muffin). Receptura poddanych ocenie produktów ekologicznych nie uwzględniała dodatku sacharozy i substancji słodzących. Ciasto wzbogacono kombinacją owoców i warzyw tj. suszone i świeże jabłka, rodzynki, burak czerwony, burak biały, dynia, marchew, śliwka, czereśnia oraz twarogiem.

Badania wykazały, iż młodzi konsumenci nie są potencjalnym segmentem nabywców produktów ekologicznych cechujących się otrzymanymi walorami sensorycznymi. Jedynie nieliczne spośród poddanych ocenie produktów były przez badaną grupę akceptowane. Z kolei najbardziej akceptowane produkty cechowały się jedynie umiarkowanym stopniem akceptowalności. Stwierdzono, iż dla młodych konsumentów walory sensoryczne (smak) żywności ekologicznej są kluczowym czynnikiem wpływającym na postawy wobec tej żywności oraz chęci jej zakupu. Wykazano, iż świadomość cech prozdrowotnych żywności ekologicznej nie gwarantuje jej nabywania.
\end{abstract}

Słowa kluczowe: akceptacja, postrzeganie, cechy sensoryczne, młodzi konsumenci, produkty piekarnicze, produkty cukiernicze, żywność ekologiczna, intencja zakupu

\begin{abstract}
This manuscript presents results of a survey aimed at evaluating attitudes of young consumers towards newly-designed, unavailable in retail ecological bakery products (10 variants of crescent rolls) and confectionery products (10 variants of muffins). Formulas of the tested bioproducts were free of saccharose and sweeteners. Dough was enriched with a mix of fruits and vegetables, i.e. dried and fresh apples, raisins, red beetroot, white beetroot, pumpkin, carrot, plump, cherry and with fresh white cheese.

The survey has demonstrated that young consumers are not a potential segment of customers of ecological products with the designed sensory values. Only few of the assessed products were acceptable by the surveyed consumers. In turn, the most acceptable products were characterized by only moderate acceptability. In the case of young consumers, the sensory values (taste) of ecological food products turned out to be the key factor affecting their attitudes towards this type of food and driving their purchase decisions. The study has shown that the awareness of health-promoting properties of bio-foods does not ensure their purchase.
\end{abstract}

Key words: acceptance, perception, sensory attributes, young consumers, bakery products, confectionery products, organic food, intention to buy

JEL Classification: Q13, L66, O31, D91

\footnotetext{
${ }^{1}$ dr inż., Katedra Towaroznawstwa, Wydział Nauk Ekonomicznych, u. Pl. Cieszyński 1, bl. 43, 10-719 Olsztyn, e-mail: mradz@uwm.edu.pl; https://orcid.org/0000-0003-0531-268X

${ }^{2}$ dr, Katedra Mikroekonomii, Wydział Nauk Ekonomicznych, e-mail: dominika.jakubowska@uwm.edu.pl; https://orcid.org/0000-0002-2797-9680

${ }^{3}$ dr inż., Katedra Podstaw Bezpieczeństwa, Wydział Nauk Technicznych, e-mail: ewa.siemianowska@uwm.edu.pl
} 


\section{Wprowadzenie}

Sektor rolnictwa ekologicznego w UE w ciagu ostatnich dziesięcioleci dość intensywnie się rozwijał. Według danych Eurostatu w 2015 roku łączna powierzchnia upraw ekologicznych w państwach członkowskich wynosiła 11,1 miliona hektarów. W ciągu ostatniej dekady obszar upraw ekologicznych powiększał się o około 500000 hektarów rocznie. Szacuje się, iż 185000 gospodarstw zajmuje się produkcją ekologiczną, z kolei uprawy ekologiczne zajmują $6,2 \%$ całkowitej powierzchni użytków rolnych w Europie. W 2015 roku zarejestrowano około 306500 operatorów ekologicznych, w tym producentów, przetwórców i importerów (Kranjac i in. 2017).

W krajach uprzemysłowionych rynek ekologicznych produktów żywnościowych uznaje się za przyszłościowy segment rynku artykułów spożywczych. W związku ze zmieniającymi się trendami w konsumpcji żywności w literaturze światowej badacze wciąż aktualizują wiedzę dotyczącą zachowań i postaw konsumentów względem żywności ekologicznej (Jovanović i in. 2016; Jiumpanyarach 2018; Larson 2018). Obszary zainteresowań badawczych obejmują $\mathrm{m}$. in. charakterystykę segmentów nabywców (Sultan i in. 2017; Pestek i Agic 2018), intencje (Ueasangkomsate i Santiteerakul 2016; Yadav i Pathak 2016; Talas i in. 2017; Mainardes i in. 2017) i bariery zakupu (Bryla 2016; Ham i in. 2016; Wojciechowska-Solis i Soroka 2017).

Jak pokazują badania krajowe, polscy konsumenci oczekują zwiększenia podaży wytwarzanych i oferowanych ekoproduktów zwłaszcza nabiału, owoców i warzyw, miodu, ziół, wędlin oraz pieczywa (Grzybek, Kawa 2017). Zmieniające się i coraz bardziej złożone oczekiwania współczesnych konsumentów w odniesieniu do produktu i jego atrybutów stawiają nowe wyzwania przed kształtującym się rynkiem żywności ekologicznej w Polsce (Żakowska-Biemans 2011). Koncepcja tworzenia nowych produktów ma na celu poszukiwanie aktualnych potrzeb konsumenta w celu stworzenia przez podmiot gospodarczy oferty produktowej zgodnej z aktualnymi trendami (Czajkowska i in. 2013). O tym czy produkt znajdzie akceptację na rynku decyduje konsument. Odgrywa on fundamentalną rolę w każdym z etapów projektowania produktu, zarówno w sferze inicjacji procesu jego tworzenia, testowania, a także wdrażania do produkcji i sprzedaży (Czajkowska i in. 2013). Poznanie oczekiwań konsumentów jest kluczowym elementem w projektowaniu nowych wyrobów (Tarczyńska 2013). Dla wielu przedsiębiorstw sektora spożywczego satysfakcja klienta stanowi miarę sukcesu stąd też na etapie projektowania wyrobów i profilowania produkcji uwzględniają oni wyniki badań oczekiwań, satysfakcji, preferencji i stopnia atrakcyjności proponowanych rozwiązań produktowych.

Wzbogacenie produktów piekarsko-cukierniczych surowcami owocowo-warzywnymi może być szansą na uzyskanie wyrobów bez dodatku sacharozy o udokumentowanej, wysokiej wartości odżywczej oraz walorach prozdrowotnych (Białek i Rutkowska 2013). Opracowanie nowych technologii innowacyjnych wyrobów piekarsko-cukierniczych wyprodukowanych bez dodatku cukru jest szansą na kreowanie prawidłowych nawyków żywieniowych u młodych pokoleń poprzez podnoszenie świadomości z zakresu zdrowego żywienia (Achremowicz i Korus 2007).

Celem zaprezentowanych $\mathrm{w}$ pracy badań było określenie postaw młodych konsumentów wobec nowo zaprojektowanych, niedostępnych w sprzedaży, ekologicznych produktów piekarniczych i cukierniczych poprzez zbadanie stopnia ich akceptacji i postrzegania. Podjęto również próbę określenia związku między postrzeganiem 
a deklarowaną intencją zakupu tych produktów. Poddano ocenie prototypy, które zostały zaprojektowane i adresowane dla uczniów i młodzieży $\mathrm{z}$ myślą o ich sprzedaży w jednostkach systemu oświaty. Produkty te wpisują się w grupę środków spożywczych przeznaczonych do sprzedaży dzieciom i młodzieży $\mathrm{w}$ jednostkach systemu oświaty (Rozporządzenie 2016), gdyż receptura poddanych ocenie wyrobów ekologicznych o udokumentowanej, wysokiej wartości odżywczej oraz walorach prozdrowotnych nie uwzględniała dodatku sacharozy i substancji słodzących.

\section{Materiał i metody badań}

Materiał badawczy stanowiło 10 wariantów rogali (oznakowanych od $1 \mathrm{r}$ do $10 \mathrm{r}$, tab. 1) oraz 10 wariantów muffin (oznakowanych od $1 \mathrm{~m}$ do $10 \mathrm{~m}$, tabela 1 ) otrzymanych $\mathrm{z}$ certyfikowanych surowców pochodzących $\mathrm{z}$ rolnictwa ekologicznego. Produkty wyprodukowano $\mathrm{w}$ zakładzie piekarniczym posiadającym certyfikat przetwórstwa ekologicznego (certyfikat Agro BIO test PL-EKO-07, nr PL-EKO-07-05901). Do produkcji wyrobów użyto dwa typy mąki: mąkę jasną Typ 500 i mąkę z pełnego przemiału otrzymane z następujących gatunków zbóż: orkiszu jarego i ozimego (Triticum spelta), pszenicy zwyczajnej (Triticum aestivum) oraz gryki (Fagopyrum Mill.) (certyfikat Agro BIO test PL-EKO-07 nr PL-EKO-07-04194).

Recepturę wyrobów piekarsko-cukierniczych opracowano na podstawie próbnego wypieku z użyciem: mąki, margaryny, jaj, drożdży oraz dodatków owocowych i warzywnych. Ciasto zostało wzbogacone różną kombinacją owoców i warzyw tj. suszone (SzJ) i świeże jabłka (SJ), rodzynki (R), burak czerwony (CB), burak biały (BB), dynia (D), marchew (M), śliwka (S), czereśnia (Cz) (certyfikat Agro BIO test nr PL EKO-07-93011 (16), certyfikat PL-EKO-01-005971). Zastosowano 10 i 20\% dodatek surowców owocowych i warzywnych w stosunku do ilości mąki w różnych wariantach, łącznie od 30$50 \%$. Niektóre warianty produktów dla podniesienia walorów smakowo-zapachowych zostały wzbogacone naturalnym przyprawami (cynamon, kardamon) i twarogiem (T). Z warzyw oraz świeżego jabłka otrzymano sok, który zastapił wodę w składzie recepturowym, rozdrobnione wytłoczyny zaś posłużyły jako wsad wzbogacający produkty w błonnik pokarmowy. Z podstawowych surowców do wypieku oraz dodatków owocowych i warzywnych w miesiarce spiralnej Eberhardt (Wagner \& Wagner) przygotowano jednolita masę na ciasto. Ciasto przygotowywano $\mathrm{w}$ temp. $20^{\circ} \mathrm{C}$ przy wolnych obrotach przez 15-20 min. Po wyrośnięciu dzielono na kęsy, formowano odpowiednie formy i wykładano na blachy. Parametry procesu wypieku zostały tak dobrane, aby zachować jak najwyższą wartość odżywczą wyrobów. Wypiek przeprowadzono w temp. $180-220{ }^{\circ} \mathrm{C}$ w piecu półkowym z palnikiem olejowym Debag Monsun w czasie 30 min. Po wystudzeniu wyroby konfekcjonowano.

Ocena produktów została przeprowadzona przez młodych konsumentów będących uczniami olsztyńskich szkół średnich oraz studentami Uniwersytetu WarmińskoMazurskiego w Olsztynie. Każdą kategorię produktów oceniło po 100 osób. Przed rozpoczęciem badań uczestnicy zostali poinformowani odnośnie bezpośredniego przygotowania do badań, przeszkoleni z zakresu stosowanej metody oceny oraz poinformowani o rodzaju i specyfice ocenianych produktów.

Badanie składało się $\mathrm{z}$ dwóch etapów. W pierwszym etapie dokonano pomiaru akceptacji przedstawionych do oceny produktów pod względem wybranych wyróżników jakości tj.: wygląd zewnętrzny, zapach, smak i ogólna pożądalność. Cechy te oceniano za 
pomocą 9-punktowej skali hedonicznej, przy czym wartości 1,2,3,4 odpowiadały odpowiedziom: wybitnie nie lubię, bardzo nie lubię, umiarkowanie nie lubię, trochę nie lubię, wartość 5 oznaczała odpowiedź: nie lubię ani nie lubię, natomiast wartości 6,7,8,9 odpowiadały odpowiedziom: umiarkowanie lubię, dość lubię, bardzo lubię, ogromnie lubię. Drugi etap badań dotyczył postrzegania produktów oraz deklarowanej intencji ich zakupu. Uczestnicy badania poproszeni zostali o ustosunkowanie się do siedmiu stwierdzeń, w stosunku do których wyrażali poziom aprobaty lub dezaprobaty, posługując się 7-stopniową skalą Likerta, przy czym wartości 1,2,3 odpowiadały odpowiedziom: zdecydowanie nie, nie, raczej nie, wartość 4 oznaczała odpowiedź nie wiem, nie mam zdania, wartości 5,6,7 odpowiadały odpowiedziom: raczej tak, tak, zdecydowanie tak.

Tabela 1. Warianty wyrobów piekarniczych i cukierniczych poddanych ocenie konsumenckiej Table 1 . Variants of bakery and confectionery products evaluated by consumers

\begin{tabular}{|c|c|c|}
\hline Kody próbek & Rodzaj i typ mąki & Procent i rodzaj dodatków \\
\hline \multicolumn{3}{|c|}{ Rogale } \\
\hline $1 \mathrm{r}$ & orkisz ozimy jasna & $20 \% \mathrm{SzJ}, 10 \% \mathrm{M}$ \\
\hline $2 \mathrm{r}$ & orkisz ozimy ciemna & $10 \% \mathrm{R}, 10 \% \mathrm{BB}, 10 \% \mathrm{D}$ \\
\hline $3 \mathrm{r}$ & pszenica zwyczajna jasna & $10 \% \mathrm{SzJ}, 10 \% \mathrm{~S}, 10 \% \mathrm{D}$ \\
\hline $4 \mathrm{r}$ & pszenica zwyczajna ciemna & $10 \% \mathrm{SzJ}, 10 \% \mathrm{M}, 10 \% \mathrm{SJ}$ \\
\hline $5 \mathrm{r}$ & orkisz jary jasna & $10 \% \mathrm{SzJ}, 10 \% \mathrm{R}, 10 \% \mathrm{CB}$ \\
\hline $6 \mathrm{r}$ & orkisz jary ciemna & $10 \% \mathrm{SzJ}, 10 \% \mathrm{R}, 10 \% \mathrm{BB}$ \\
\hline $7 \mathrm{r}$ & orkisz ozimy jasna & $10 \% \mathrm{R}, 10 \% \mathrm{SJ}, 10 \% \mathrm{~T}$ \\
\hline $8 \mathrm{r}$ & orkisz ozimy ciemna & $10 \% \mathrm{SzJ}, 10 \% \mathrm{~S}, 10 \% \mathrm{CB}$ \\
\hline $9 \mathrm{r}$ & pszenica zwyczajna jasna & $10 \% \mathrm{SzJ}, 10 \% \mathrm{M}, 10 \% \mathrm{BB}$ \\
\hline $10 \mathrm{r}$ & pszenica zwyczajna ciemna & $10 \% \mathrm{SzJ}, 10 \% \mathrm{~S}, 10 \% \mathrm{~T}$ \\
\hline \multicolumn{3}{|c|}{ Muffiny } \\
\hline $1 \mathrm{~m}$ & orkisz jary jasna & $10 \%$ SzJ, $10 \%$ R, $20 \% \mathrm{D}, 10 \% \mathrm{SJ}$ \\
\hline $2 \mathrm{~m}$ & orkisz jary ciemna & $10 \% \mathrm{SzJ}, 10 \% \mathrm{~S}, 20 \% \mathrm{M}, 10 \% \mathrm{SJ}$ \\
\hline $3 \mathrm{~m}$ & orkisz ozimy jasna & $10 \% \mathrm{SzJ}, 20 \% \mathrm{BB}, 10 \% \mathrm{SJ}, 10 \% \mathrm{Cz}$ \\
\hline $4 \mathrm{~m}$ & orkisz ozimy ciemna & $10 \% \mathrm{R}, 20 \% \mathrm{CB}, 20 \% \mathrm{SJ}$ \\
\hline $5 \mathrm{~m}$ & gryka & $10 \% \mathrm{R}, 20 \% \mathrm{M}, 20 \% \mathrm{SJ}$ \\
\hline $6 \mathrm{~m}$ & pszenica zwyczajna jasna & $10 \% \mathrm{SJ}, 10 \% \mathrm{R}, 20 \% \mathrm{M}, 10 \% \mathrm{SJ}$ \\
\hline $7 \mathrm{~m}$ & pszenica zwyczajna ciemna & $10 \% \mathrm{SJ}, 10 \% \mathrm{~S}, 20 \% \mathrm{CB}, 10 \% \mathrm{SJ}$ \\
\hline $8 \mathrm{~m}$ & orkisz jary jasna & $10 \% \mathrm{SJ}, 10 \% \mathrm{~S}, 20 \% \mathrm{BB}, 10 \% \mathrm{D}$ \\
\hline $9 \mathrm{~m}$ & orkisz jary ciemna & $10 \% \mathrm{SJ}, 10 \% \mathrm{~S}, 20 \% \mathrm{D}, 10 \% \mathrm{SJ}$ \\
\hline $10 \mathrm{~m}$ & Gryka & $10 \% \mathrm{SJ}, 20 \% \mathrm{CB}, 10 \% \mathrm{BB}, 10 \% \mathrm{Cz}$ \\
\hline
\end{tabular}

Źródło: Badania własne.

Uzyskane wyniki poddano analizie statystycznej za pomocą programu Statistica 13.1. Wyznaczono statystyki podstawowe: średnią (x), odchylenie standardowe (SD), medianę (M), \% wskazań. Związki między postrzeganiem przedstawionych do oceny produktów 
a deklarowaną behawioralną intencją ich zakupu zbadano wykorzystując analizę korelacji na dwóch poziomach istotności: $\mathrm{p}=0,05$ i p=0,001.

\section{Wyniki badań i ich omówienie}

W tabeli 2 przedstawiono wyniki oceny wyróżników jakości badanych próbek rogali i muffin. Średnie ocen wyglądu zewnętrznego, zapachu, smaku i ogólnej pożądalności

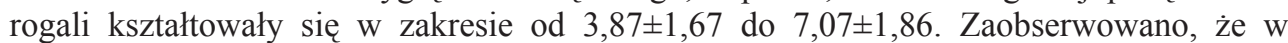
odniesieniu do cech organoleptycznych wielu wariantów rogali młodzi konsumenci najczęściej wyrażali ambiwalentny $(\mathrm{M}=5)$ lub trochę negatywny stosunek $(\mathrm{M}=4)$. Odnotowano, iż najbardziej akceptowanym wariantem pod kątem wyglądu zewnętrznego był produkt oznakowany jako $1 \mathrm{r}$ (średnia ocen: $6,77 \pm 1,48, \mathrm{M}=7$ ), wyprodukowany z mąki orkiszowej ozimej jasnej, wzbogacony $20 \%$ suszonych jabłek oraz $10 \%$ marchwi. Z kolei próbka ta najczęściej $\mathrm{w}$ ocenie badanych nie odznaczała się jednak akceptowanym

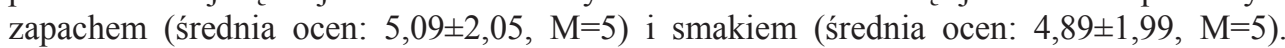
Badania wykazały, że wyróżniającym się produktem pod względem zapachu (średnia ocen: $7,07 \pm 1,86, \mathrm{M}=8$ ) i smaku (średnia ocen: $6,76 \pm 1,96, \mathrm{M}=7$ ) była próbka $7 \mathrm{r}$ otrzymana z mąki orkiszowej ozimej jasnej wzbogacona $10 \%$ rodzynek, $10 \%$ świeżych jabłek i $10 \%$ twarogu. Akceptowalność omawianych wyróżników jakości miała przełożenie na wyższy (kształtujący się na poziomie 6,33 - umiarkowanie lubię/dość lubię) stopień pożądalności tej próbki w odniesieniu do pozostałych. Jak pokazują badania młodzież nisko oceniła cechy organoleptyczne poddanych ocenie muffin. Pod względem wyglądu zewnętrznego cztery spośród produktów $(1 \mathrm{~m}, 5 \mathrm{~m}, 6 \mathrm{~m}$ i $8 \mathrm{~m})$ były najczęściej, jednak w niewielkim stopniu akceptowane przez większość badanych $(\mathrm{M}=6)$. Generalnie próbki te w ocenie konsumentów nie odznaczały się jednak akceptowanym zapachem, smakiem i ogólną pożąalnością. Podobnie w przypadku pozostałych produktów wartości średnie i mediany

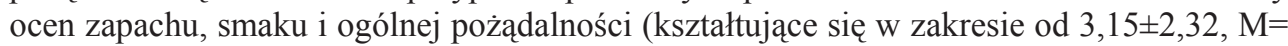
2 do $5,17 \pm 1,58, M=5$ ) sugeruja, iż poddane ocenie warianty muffin nie były akceptowane pod względem tych wyróżników jakości.

W kolejnej cześci badania dokonano oceny postrzegania i intencji zakupu ekologicznych produktów (tabele 3 i 4). Jak wynika z przeprowadzonych badań młodzież była przekonana o zdrowotności poddanych ocenie rogali i muffin (odpowiednio $98 \%$ i $92 \%$ badanych oceniało te produkty jako zdrowe). Zdaniem większości badanych (76\% oceniających rogale oraz $63 \%$ oceniających muffiny) produkty te charakteryzowały się wysoką jakością.

Analizując postawy wobec ocenianych próbek rogali, $71 \%$ uczestników badania oceniła próbki pozytywnie, przy czym jedynie 3\% z nich zdecydowanie pozytywnie. Zdaniem większości produkty te powinny być spożywane przez młodzież ( $88 \%$ wskazań). Badani twierdzili, iż wprowadzenie ich do sprzedaży jest raczej dobrym (22\%), dobrym $(29 \%)$ i zdecydowanie dobrym pomysłem $(13 \%)$. Generalnie wyroby te zostały ocenione przez większość badanych jako konkurencyjne na rynku (66\% wskazań). Należy jednak podkreślić, iż jedynie $8 \%$ uczestników badania oceniło produkty jako zdecydowanie konkurencyjne. 
Tabela 2. Ocena organoleptyczna ekologicznych produktów piekarniczych i cukierniczych

Table 2. Organoleptic evaluation of organic bakery and confectionery products

\begin{tabular}{|c|c|c|c|c|c|c|c|c|}
\hline \multirow{3}{*}{ Kody } & \multicolumn{8}{|c|}{ Wyróżniki jakości organoleptycznej } \\
\hline & \multicolumn{2}{|c|}{ wygląd zewnętrzny } & \multicolumn{2}{|l|}{ zapach } & \multicolumn{2}{|l|}{ smak } & \multicolumn{2}{|c|}{ ogólna pożądalność } \\
\hline & $\mathrm{x} \pm \mathrm{SD}$ & M & $\mathrm{x} \pm \mathrm{SD}$ & M & $\mathrm{x} \pm \mathrm{SD}$ & M & $\mathrm{x} \pm \mathrm{SD}$ & M \\
\hline \multicolumn{9}{|c|}{ rogale } \\
\hline $1 \mathrm{r}$ & $6,77 \pm 1,48$ & 7 & $5,09 \pm 2,05$ & 5 & $4,89 \pm 1,99$ & 5 & $5,17 \pm 1,91$ & 5 \\
\hline $2 \mathrm{r}$ & $5,80 \pm 1,80$ & 6 & $4,64 \pm 1,96$ & 5 & $3,87 \pm 1,67$ & 4 & $4,28 \pm 1,71$ & 4 \\
\hline $3 \mathrm{r}$ & $5,92 \pm 1,51$ & 6 & $4,87 \pm 1,94$ & 4 & $5,09 \pm 1,73$ & 5 & $5,06 \pm 1,76$ & 5 \\
\hline $4 \mathrm{r}$ & $4,70 \pm 1,11$ & 5 & $4,05 \pm 1,32$ & 4 & $4,19 \pm 1,66$ & 4 & $4,03 \pm 1,39$ & 4 \\
\hline $5 \mathrm{r}$ & $5,53 \pm 1,78$ & 5 & $5,27 \pm 1,64$ & 5 & $5,14 \pm 1,68$ & 5 & $4,85 \pm 1,82$ & 5 \\
\hline $6 r$ & $5,46 \pm 1,67$ & 6 & $4,64 \pm 1,54$ & 5 & $4,28 \pm 1,77$ & 4 & $4,42 \pm 1,70$ & 4 \\
\hline $7 \mathrm{r}$ & $6,26 \pm 1,61$ & 6 & $7,07 \pm 1,86$ & 8 & $6,76 \pm 1,96$ & 7 & $6,33 \pm 2,17$ & 7 \\
\hline $8 \mathrm{r}$ & $5,44 \pm 1,82$ & 6 & $5,14 \pm 1,92$ & 5 & $5,14 \pm 1,86$ & 5 & $4,71 \pm 1,85$ & 5 \\
\hline $9 \mathrm{r}$ & $4,24 \pm 0,96$ & 4 & $4,26 \pm 1,76$ & 4 & $4,68 \pm 1,50$ & 5 & $4,15 \pm 1,07$ & 4 \\
\hline $10 \mathrm{r}$ & $5,56 \pm 1,98$ & 5 & $4,28 \pm 1,50$ & 4 & $4,02 \pm 1,23$ & 5 & $4,12 \pm 1,27$ & 4 \\
\hline \multicolumn{9}{|c|}{ muffiny } \\
\hline $1 \mathrm{~m}$ & $6,13 \pm 1,76$ & 6 & $4,87 \pm 1,60$ & 5 & $4,76 \pm 2,15$ & 4 & $4,03 \pm 1,82$ & 4 \\
\hline $2 \mathrm{~m}$ & $5,17 \pm 1,58$ & 5 & $4,88 \pm 1,43$ & 5 & $4,52 \pm 1,79$ & 4 & $4,56 \pm 1,66$ & 5 \\
\hline $3 \mathrm{~m}$ & $4,95 \pm 1,80$ & 5 & $4,46 \pm 1,39$ & 4 & $4,06 \pm 2,04$ & 4 & $4,24 \pm 1,68$ & 4 \\
\hline $4 \mathrm{~m}$ & $4,95 \pm 1,59$ & 5 & $4,65 \pm 1,57$ & 5 & $4,33 \pm 2,10$ & 4 & $4,40 \pm 1,66$ & 4 \\
\hline $5 \mathrm{~m}$ & $6,12 \pm 1,66$ & 6 & $4,86 \pm 1,44$ & 5 & $3,97 \pm 1,78$ & 4 & $4,46 \pm 1,59$ & 5 \\
\hline $6 \mathrm{~m}$ & $5,74 \pm 1,70$ & 6 & $5,61 \pm 1,58$ & 6 & $5,21 \pm 1,88$ & 5 & $4,81 \pm 1,83$ & 5 \\
\hline $7 \mathrm{~m}$ & $4,55 \pm 1,87$ & 5 & $4,68 \pm 1,40$ & 5 & $4,05 \pm 1,81$ & 4 & $4,06 \pm 1,75$ & 4 \\
\hline $8 \mathrm{~m}$ & $5,46 \pm 1,62$ & 6 & $5,04 \pm 1,72$ & 5 & $4,34 \pm 1,77$ & 4 & $4,03 \pm 1,62$ & 4 \\
\hline $9 \mathrm{~m}$ & $5,05 \pm 1,82$ & 5 & $4,54 \pm 1,69$ & 4 & $4,03 \pm 2,05$ & 4 & $4,21 \pm 1,80$ & 4 \\
\hline $10 \mathrm{~m}$ & $4,09 \pm 2,10$ & 4 & $4,24 \pm 2,38$ & 4 & $3,15 \pm 2,32$ & 2 & $3,16 \pm 2,04$ & 3 \\
\hline
\end{tabular}

Źródło: Badania własne.

Tabela 3. Rozkład odpowiedzi na poszczególne stwierdzenia odnoszące się do postrzegania i intencji zakupu ekologicznych rogali

Table 3. Distribution of responses to individual statements referring to the perception and intentions of purchasing organic croissants

\begin{tabular}{l|c|c|c|c|c|c|c}
\hline \multicolumn{1}{c}{ Stwierdzenia } & \multicolumn{5}{c}{ Opinie badanych (w \%) } \\
\cline { 2 - 8 } & 1 & 2 & 3 & 4 & 5 & 6 & 7 \\
\hline Badane próbki oceniam pozytywnie & 0 & 4 & 4 & 21 & 27 & 41 & 3 \\
\hline Oceniane produkty są wysokiej jakości & 2 & 3 & 8 & 11 & 19 & 39 & 18 \\
\hline Oceniane produkty są zdrowe & 0 & 0 & 0 & 2 & 7 & 38 & 53 \\
\hline Oceniane produkty powinny być spożywane przez młodzież & 0 & 2 & 0 & 10 & 21 & 32 & 35 \\
\hline Oceniane produkty są konkurencyjne na rynku & 5 & 4 & 13 & 12 & 37 & 21 & 8 \\
\hline Wprowadzenie do sprzedaży ocenianych produktów to dobry pomysł & 1 & 3 & 14 & 18 & 22 & 29 & 13 \\
\hline $\begin{array}{l}\text { Jeśli oceniane produkty będą dostępne w sklepach to wyrażam chęć } \\
\text { (zamiar) ich nabywania (zakupu) }\end{array}$ & 2 & 2 & 23 & 9 & 43 & \multirow{2}{*}{19} & 2 \\
\hline
\end{tabular}

1 - zdecydowanie nie, 2 - nie, 3 - raczej nie, 4 - nie wiem, nie mam zdania, 5 - raczej tak, 6 - tak, 7 - zdecydowanie tak.

Źródło: Badania własne. 


\section{M. Radzymińska, D. Jakubowska, E. Siemianowska}

$\mathrm{Z}$ kolei tylko $38 \%$ badanych prezentowała pozytywne postawy wobec muffin, co związane było z niską oceną wyróżników organoleptycznych tych produktów. Pomimo, iż większość konsumentów uważała te wyroby za wysokiej jakości, jedynie $22 \%$ badanych uznało te produkty za konkurencyjne na rynku. Natomiast zdaniem $40 \%$ wprowadzenie do sprzedaży tych produktów jest raczej dobrym, dobrym i zdecydowanie dobrym pomysłem.

Tabela 4. Rozkład odpowiedzi na poszczególne stwierdzenia odnoszące się do postrzegania i intencji zakupu ekologicznych muffin

Table 4. Distribution of responses to individual statements referring to the perception and intentions of purchasing organic muffins

\begin{tabular}{l|c|c|c|c|c|c|c}
\hline \multicolumn{1}{c|}{ Stwierdzenia } & \multicolumn{5}{c}{ Opinie badanych (w \%) } \\
\cline { 2 - 7 } & 1 & 2 & 3 & 4 & 5 & 6 & 7 \\
\hline Badane próbki oceniam pozytywnie & 0 & 9 & 31 & 22 & 19 & 16 & 3 \\
\hline Oceniane produkty są wysokiej jakości & 1 & 4 & 11 & 21 & 32 & 19 & 12 \\
\hline Oceniane produkty są zdrowe & 0 & 0 & 0 & 8 & 21 & 27 & 44 \\
\hline Oceniane produkty powinny być spożywane przez młodzież & 1 & 0 & 3 & 24 & 33 & 25 & 14 \\
\hline Oceniane produkty są konkurencyjne na rynku & 8 & 13 & 24 & 33 & 13 & 7 & 2 \\
\hline Wprowadzenie do sprzedaży ocenianych produktów to dobry pomysł & 4 & 7 & 23 & 26 & 18 & 18 & 4 \\
\hline $\begin{array}{l}\text { Jeśli oceniane produkty będą dostępne w sklepach to wyrażam chęć } \\
\text { (zamiar) ich nabywania (zakupu) }\end{array}$ & 9 & 11 & 32 & 24 & 19 & 4 & 1 \\
\hline
\end{tabular}

1 - zdecydowanie nie, 2 - nie, 3 - raczej nie, 4 - nie wiem, nie mam zdania, 5 - raczej tak, 6 - tak, 7 - zdecydowanie tak

Źródło: Badania własne.

W badaniu poddano ocenie deklarowaną przez młodzież chęć zakupu produktów. $\mathrm{Z}$ deklaracji $43 \%$ badanych wynika, że byliby raczej skłonni nabywać rogale w momencie ich rynkowej dostępności. Z kolei $19 \%$ skłonna byłaby nabywać te produkty, a jedynie $2 \%$ wyrażała zdecydowaną chęć nabywania tych produktów. W przypadku muffin jedynie $24 \%$ badanych wyrażało chęć nabywania tych produktów jeśli byłyby dostępne.

Tabela 5. Zależności między postrzeganiem a deklarowaną intencją zakupu produktów ekologicznych

Table 5. Relations between perception and the declared intention of purchasing organic products

\begin{tabular}{l|c|c}
\hline \multirow{2}{*}{ Postrzeganie produktów } & \multicolumn{2}{|c}{ Intencja zakupu } \\
\cline { 2 - 3 } & rogale & muffiny \\
\hline Badane próbki oceniam pozytywnie & $0,53 * *$ & $0,61^{* *}$ \\
Oceniane produkty są wysokiej jakości & $0,39^{* *}$ & 0,19 \\
Oceniane produkty są zdrowe & $0,25^{*}$ & 0,14 \\
Oceniane produkty powinny być spożywane przez młodzież & 0,16 & $0,29 *$ \\
Oceniane produkty są konkurencyjne na rynku & $0,38^{* *}$ & $0,56^{* *}$ \\
Wprowadzenie do sprzedaży ocenianych produktów to dobry pomysł & $0,53^{* *}$ & $0,54^{* *}$ \\
\hline
\end{tabular}

* zależności istotne statystycznie $(p<0,05) ; * *$ zależności istotne statystycznie $(p<0,001)$

Źródło: Badania własne.

W prezentowanym badaniu podjęto próbę określenia relacji (istotności i siły zależności) między postrzeganiem produktów a intencją ich zakupu. Na podstawie analizy 
wyznaczonych współczynników korelacji dwustronnej między zmiennymi (tabela 5) wykazano, iż najsilniej skorelowane $\mathrm{z}$ intencją zakupu były prezentowane przez konsumentów postawy wobec ocenianych produktów (w przypadku rogali i muffin odpowiednio: $r=0,53, p<0,001$ i $r=0,61, p<0,001$, korelacje wysokie). Stwierdzono również, iż intencja zakupu produktów jest statystycznie istotnie związana $(p<0,001) \mathrm{z}$ ich postrzeganiem $\mathrm{w}$ kontekście dobrego pomysłu rynkowego (w przypadku rogali i muffin odpowiednio: $\mathrm{r}=0,53$ i $\mathrm{r}=0,54$, korelacje wysokie) oraz rynkowej konkurencyjności (w przypadku rogali i muffin odpowiednio: $\mathrm{r}=0,38 \mathrm{i} \mathrm{r}=0,56$, korelacje przeciętna i wysoka). Ponadto stwierdzono statystycznie istotne związki $(\mathrm{p}<0,001)$ między intencją zakupu rogali a postrzeganą wysoką jakością tych produktów ( $\mathrm{r}=0,39$, korelacja przeciętna) oraz statystycznie istotną słabą zależność $(p<0,05)$ między intencją zakupu muffin a postrzeganiem tych produktów jako atrakcyjnych dla młodzieży $(r=0,29)$. Statystycznie istotną $(\mathrm{p}<0,05)$ lecz słabą zależność odnotowano między przekonaniem o zdrowotności poddanych ocenie rogali a deklarowaną intencją ich zakupu $(\mathrm{r}=0,25)$.

$\mathrm{Z}$ przedstawionych badań wynika, iż w grupie młodych konsumentów świadomość cech prozdrowotnych żywności ekologicznej nie gwarantuje jej nabywania. Jak wynika z danych umieszczonych w tabelach 3 i 4 jedynie nieliczni z osób wyrażających zdecydowanie pozytywne opinie dotyczące zdrowotności produktów (w przypadku rogali i muffin odpowiednio: 53\% i 44\% badanych) zdecydowanie deklarowali chęć nabywania tych produktów (w przypadku rogali i muffin odpowiednio: $2 \%$ i 1\%).

Z krajowych danych wynika, że najwyższy udział konsumentów dokonujących zakupu żywności ekologicznej stanowią osoby młode (od 26 do 35 roku) i w wieku średnim (od 36 do 45 roku). Za decyzje zakupowe żywności ekologicznej odpowiedzialne są głównie kobiety. Konsumenci żywności ekologicznej wyróżniają się wyższym poziomem wykształcenia oraz dobrą sytuacja dochodową (Żakowska-Biemans 2011). Analiza literatury anglojęzycznej daje niejednoznaczny obraz profilu konsumenta żywności ekologicznej w różnych krajach. Z jednej strony wskazuje, że konsumentami żywności ekologicznej są głownie kobiety cechujące się wysokim poziomem wykształcenia, w wieku ponad 30 lat (Turra i in. 2015), z drugiej zaś zazwyczaj osoby starsze i bardziej wykształcone (Sangkumchaliang i Huang 2012; Toit i Crafford 2013; Rameshi Divya 2015). Stwierdzono, że odsetek osób spożywających żywność ekologiczną rośnie wraz ze wzrostem dochodów (Torjusen i in. 2001) i poziomem wykształcenia (Lockie i in. 2002; Storstad i Bjorkhaug, 2003). Ponadto odnotowano, iż mieszkańcy miast są bardziej skłonni spożywać organiczne produkty żywnościowe w porównaniu do zamieszkałych na obszarach wiejskich (Connor i Douglas 2001). Rola zmiennych socjodemograficznych w wyjaśnianiu zachowań konsumentów na rynku żywności ekologicznej jest wciąż w literaturze przedmiotem dyskusji. Podkreśla się ograniczony wpływ zmiennych społecznodemograficznych w wyjaśnianiu dokonywanych wyborów żywności ekologicznej. Wiele badań wskazuje, że kwestie zdrowotne stanowią główny powód zakupu żywności ekologicznej, a atrybuty zdrowotne stały się równie ważne jak sensoryczne w procesie podejmowania decyzji o zakupie (Aygen 2012; Meixner i in. 2014; Irianto 2015; Yadav i Pathak 2016; Oroian i in. 2017). Przy podejmowanych decyzjach o zakupie żywności ekologicznej atrybuty zdrowotne mogą jednak zajmować różne pozycje w odniesieniu do cech sensorycznych produktów. Dla duńskich i brytyjskich konsumentów aspekt zdrowotny jest głównym powodem zakupu żywności ekologicznej po smaku i świeżości (Wier i in. 2008). Francuscy konsumenci kupują produkty ekologiczne głównie ze względu na ich smak a w dalszej kolejności ze względu na korzyści zdrowotne (Baudry i in. 2017). Polscy 
konsumenci uważają, że zdrowie i wysoka jakość to najważniejsze cechy produktów ekologicznych (Bryla 2016). Ponadto z badań ogólnopolskich zrealizowanych wśród konsumentów zaopatrujących się w sklepach z żywnością ekologiczną wynika, iż najważniejszymi motywami zakupu są troska o zdrowie, przekonanie o jej bezpieczeństwie. Smak żywności ekologicznej jako czynnik motywujący do zakupu jest oceniany zdecydowanie wyżej aniżeli wygląd żywności ekologicznej (Żakowska-Biemans 2011). Wyniki badań indonezyjskich autorów (Wahyudi i Ardiansyah 2017) pokazują, że młodzi konsumenci postrzegają produkty ekologiczne jako zdrowsze, lepiej smakujące, cechujące się wyższą jakością i bezpieczniejsze, w porównaniu do żywności konwencjonalnej.

Postrzeganie produktów ma kluczowe znaczenie w decyzjach nabywczych i uważane jest za determinantę intencji ich nabywania i konsumpcji. W literaturze liczne prace podejmują się studiów wpływu postrzegania żywności ekologicznej na intencję jej zakupu (Honkanen i in. 2006; Michaelidou i Hassan 2008; Wee i in. 2014; Ueasangkomsate i Santiteerakul 2016). Podkreślić należy jednak ograniczenia tych badań wynikające $\mathrm{z}$ nieuwzględnienia $\mathrm{w}$ nich oceny wyróżników jakości sensorycznej produktów. Podjęte w niniejszej pracy badania odnoszą się do oceny postrzegania i intencji zakupu produktów ekologicznych, których warianty zostały zaprezentowane badanym oraz poddane konsumenckiej ocenie sensorycznej.

Opinie konsumentów stanowią podstawę do oceny koncepcji wytwarzania nowych produktów (Czajkowska i in. 2013). Młodzi konsumenci to szczególnie wymagająca grupa, która preferuje smaki słodkie. Przeprowadzone badania wykazały, iż smak jest kluczowym czynnikiem wpływającym na postawy wobec żywności ekologicznej oraz intencje jej zakupu. Jedynie nieliczne zaprojektowane, poddane ocenie warianty nowych produktów były przez młodych konsumentów akceptowane. Konieczne jest zatem przy współpracy konsumenta dalsze doskonalenie specyfikacji produktowej dotyczące receptury produktów przy jednoczesnym zachowaniu ich wysokiej wartości odżywczej oraz walorach prozdrowotnych.

\section{Wnioski}

Poddane ocenie konsumenckiej zaprojektowane produkty piekarnicze i cukiernicze wyprodukowane bez dodatku sacharozy i chemicznych środków spulchniających, wzbogacone kombinacją świeżych i suszonych owoców oraz warzyw charakteryzowały się wysoką wartości odżywczą z powodu koncentracji substancji bioaktywnych (tj. błonnik pokarmowy, polifenole) oraz walorami prozdrowotnymi. Badania wykazały, iż młodzi konsumenci nie są potencjalnym segmentem nabywców produktów ekologicznych cechujących się otrzymanymi walorami sensorycznymi. Jedynie nieliczne spośród badanych produktów były przez młodych konsumentów akceptowane. Produkty te cechowały się tylko umiarkowanym stopniem akceptowalności. Stwierdzono, iż dla młodych konsumentów walory sensoryczne (smak) żywności ekologicznej są kluczowym czynnikiem wpływającym na postawy wobec tej żywności oraz chęci jej zakupu. Wykazano, iż świadomość cech prozdrowotnych żywności ekologicznej nie gwarantuje jej nabywania. Mimo przekonania o zdrowotności prezentowanych produktów ekologicznych badana młodzież nie deklarowała zdecydowanej chęci ich zakupu w momencie rynkowej dostępności. Wybór żywności ekologicznej przez młodych konsumentów nie jest więc związany $\mathrm{z}$ troską o zdrowie czy przekonaniem o jakości zdrowotnej tych produktów. Aby zainteresować ten segment nabywców konieczne jest dalsze doskonalenie 
receptury produktów pod kątem cech sensorycznych jednocześnie przy zachowaniu wysokich walorów jakościowych produktów.

Zaprezentowane $w$ pracy wyniki stanowiq fragment sfinansowanych przez MRiRW ,, badań nad opracowaniem optymalnej technologii produkcji wyrobów piekarskich $i$ cukierniczych wzbogacanych świeżymi i suszonymi owocami $i$ warzywami, spetniajacych kryteria zawarte w pozycji 1256 Rozporzadzenia Ministra Zdrowia $z$ dnia 28 sierpnia 2015 r.", decyzja MRiRW nr HOR-re-msz-078-8/16 (224) z dnia 20 maja 2016 r.

\section{Literatura}

Achremowicz, B., Korus, J. (2007). Potrzeba regulacji zawartości izomerów trans kwasów tłuszczowych w żywności (The necessity of the regulation on Trans Fatty acid content in food). Żywność. Nauka. Technologia. Jakość, 52(3), 5-14.

Aygen, F.G. (2012). Attitudes and behavior of Turkish consumers with respect to organic foods. International Journal of Business and Social Science, 3, 262-273.

Baudry, J., Péneau, S., Allès, B., Touvier, M., Hercberg, S., Galan, P., Amiot, M.J., Lairon, D., Méjean, C., Kesse-Guyot, E. (2017). Food choice motives when purchasing in organic and conventional consumer clusters: Focus on sustainable concerns (The NutriNet-Santé Cohort Study). Nutrients, 9, 1-17.

Białek, M., Rutkowska, J. (2013). Potencjalne wykorzystanie prozdrowotnych surowców roślinnych do zwiększenia wartości odżywczej wyrobów ciastkarskich (Potential use of helthepromoting plant raw materials to increase the nutritional value of confectionery products). Episteme, 21, 187-20.

Bryla, P. (2016). Organic food consumption in Poland: Motives and barriers. Appetite, 105, 737-746.

Connor, R., Douglas, L. (2001). Applied consumer science: Consumer attitudes to organic foods. Nutrition and Food Science, 31 (4/5), 254-258.

Czajkowska, K., Kowalska, H., Piotrowski, D. (2013). Rola konsumenta w procesie projektowania nowych produktów spożywczych (The role of consumer in the process of new food products design). Zeszyty Problemowe Postęów Nauk Rolniczych, 575, 23-32.

Grzybek, M, Kawa, M. (2017). Expectations of podkarpacie residents with regard to offers of organic food products of regional origin. Journal of Agribusiness and Rural Development, 1(43), 79-85.

Ham, M., Pap A., Bilandžić, K. (2016). Percieved barriers for buying organic food products. 18th International Scientific Conference on Economic and Social Development - Building Resilient Society. Zagreb, Croatia, 9-10 December 2016. Pobrano z: https://bib.irb.hr/datoteka/849393.Ham_Pap_Bilandi.pdf.

Honkanen, P., Verplanker, B., Olsen, S.O. (2006). Ethical values and motives driving organic food choice. Journal of Consumer Behaviour, 5(5), 420-430.

Irianto, H. (2015). Consumers' attitude and intention towards organic food purchase: An extension of theory of planned behavior in gender perspective. International Journal of Management, Economics and Social Sciences, 2015, 4(1), 17-31.

Jiumpanyarach, W. (2018). The impact of social trends: teenagers' attitudes for organic food market in Thailand International Journal of Social Economics, DOI 10.1108/IJSE-01-2017-0004.

Jovanović, M., Joksimović, M., Kašćelan, I., Despotović, A. (2016). Consumer attitudes to organic foods: evidence from montenegrin market. Agriculture \& Forestry, 62(4): 223-234.

Kranjac, M, Vapa-Tankosić, J., Knežević, M. (2017). Profile of organic food consumers. Economics of Agriculture, (64)2, 497-514.

Larson, R.B. (2018). Examining consumer attitudes toward genetically-modified and organic foods. British Food Journal, DOI 10.1108/BFJ-09-2017-0502.

Lockie, S., Lyons, K., Lawrence, G. and Mummery, K. (2001). Eating "green": motivations behind organic food consumption in Australia. Sociologia Ruralis, 42,1, 23-40.

Mainardes, E.W., Borell, A., Lasso, S., Andrade, D.M. (2017). Influences on the intention to buy organic food in an emerging market. Marketing Intelligence \& Planning, 35(7), 858-876.

Meixner, O., Haas, R., Perevoshchikova, Y., Canavari, M. (2014). Consumer attitudes, knowledge, and behavior in the russian market for organic food. International Journal on Food System Dynamic, 5, 110-120.

Michaelidou, N., Hassan, L.M. (2008). The role of health consciousness, food safety concern and ethical identity on attitudes and intentions towards organic food. International Journal of Consumer Studies, 32(2): 163-170.

Oroian, C.F, Safirescu, C.O., Harun, R., Chiciudean, G.O., Arion, H., Muresan, I.C., Bordeanu, B.M. (2017). Consumers' Attitudes towards Organic Products and Sustainable Development: A Case Study of Romania. Sustainability, 9(9),1-14. 
Pestek, A., Agic, E. (2018). Segmentation or organic food buyers: an emergent market perspective. British Food Journal, 120(10):00-00 DOI10.1108/BFJ-04-2017-0215

Ramesh, S.V., Divya, M. (2015). A study on consumers' awareness attitude and satisfaction towards select organic food products with reference to Coimbatore. International Journal of Interdisciplinary Multidisciplinary Studies, 2(4), 81-84.

Rozporządzenia Ministra Zdrowia z dnia 26 lipca 2016 roku w sprawie grup środków spożywczych przeznaczonych do sprzedaży dzieciom i młodzieży w jednostkach systemu oświaty oraz wymagań, jakie muszą spełniać środki spożywcze stosowane w ramach żywienia zbiorowego dzieci i młodzieży w tych jednostkach. Dz.U. 2016 poz. 1154.

Sangkumchaliang, P. Huang, W.Ch. (2012). Consumers' perceptions and attitudes of organic food products in Northern Thailand. International Food and Agribusiness Management Review, 15, 87-102.

Storstad, O., Bjorkhaug, H. (2003). Foundations of production and consumption of organic food in Norway: common attitudes among farmers and consumers. Agriculture and Human Values, 20,151-63.

Sultan P., Wong H.Y., Sigala M. (2017). Segmenting the Australian organic food consumer market. Asia Pacific Journal of Marketing and Logistics 30(11):00-00. DOI 10.1108/APJML-10-2016-0211

Talas, M.A., Toprak, L., Altürki, A., Yüksel, T.A., Gürbüz, S., Çimar, S.S. (2017). Consumers’ Intention to Buy Organic Food: Applying TPB. 1st International Organic Agriculture and Biodiversity Symposium 27-29 September 2017 Bayburt" "I. Uluslararası Organik Tarım ve Biyoçeşitlilik Sempozyumu 27-29 Eylül Baybur. Pobrano z: file:///C:/Users/UWM/Downloads/ORGANK.pdf

Tarczyńska A.S. (2013). Projektowanie żywności wygodnej z wykorzystaniem metody QFD (Developing convenient food products using qfd method). Żywność. Nauka. Technologia. Jakość, 3(88), 187-199.

Toit, L.; Crafford, S. (2003). Beliefs and purchasing practices of Cape Town consumers regarding organically produced food. Journal of Family Ecology and Consumer Sciences, 31, 1-11.

Torjusen, H., Lieblien, G., Wandel, M. and Francis, C.A. (2001). Food system orientation and quality perception among consumers and producers of organic food in Hedmark County, Norway. Food Quality and Preference, 12, 207-16.

Turra, Ch., Ghisi Nielsen, F.A., De Freitas Vian, C.E., Moreira, C.F. Ferrarezi, A.C. (2015). The Brazilian consumer's profile and perceptions of organic foods: a review. Global Advanced Research Journal of Agricultural Science 4(11), 775-783.

Ueasangkomsate, P., Santiteerakul, S. (2016). A study of consumers' attitudes and intention to buy organic foods for sustainability. Procedia Environmental Sciences, 34, 423-430.

Wahyudi, D., Ardiansyah, A. (2017). Perceptions of young consumers toward organic food in Indonesia. International Journal of Agricultural Resources, Governance and Ecology, 13(4), 315-324.

Wee, Ch.S.,_Arif, M.S.B.M, Zakuan, N, Tajudin, M.N.T.,_Ismail, K., Ishak, N. (2014): Consumers perception, purchase intention and actual purchase behavior of organic food products. Review of Integrative Business and Economics Research, 3(2), 378-397.

Wier, M. O'Doherty Jensen, K., Andersen, L.M., Millock, K., Rosenkvist, L. (2008). The character of demand in mature organic food markets: Great Britain and Denmark compared. Food Policy, 33, 406-421.

Wojciechowska-Solis, J., Soroka, A. (2017): Motives and barriers of organic food demand among Polish consumers. A profile of the purchasers. British Food Journal, 119(9), 2040-2048.

Yadav, R., Pathak, G.S. (2016). Intention to purchase organic food among young consumers: Evidences from a developing nation. Appetite, 96, 122-128.

Żakowska-Biemans, S. (2011). Czynniki warunkujące popyt na żywność ekologiczną w kontekście przeobrażeń rynku żywności ekologicznej w Polsce i innych krajach Europy (Factors determining the demand for organic food in the context of transformations of the organic food market in Poland and other European countries). Raport z badań. Pobrano z: http://wnzck.sggw.pl/wp-content/uploads/2015/08/Raport koncowy_dotacja_MINROL_2011.pdf).

Do cytowania / For citation:

Radzymińska M., Jakubowska D., Siemianowska E. (2018). Postawy młodych konsumentów wobec ekologicznych produktów piekarniczych i cukierniczych - studium przypadku. Problemy Rolnictwa Światowego, 18(2), 238-248; DOI: 10.22630/PRS.2018.18.2.51

Radzymińska M., Jakubowska D., Siemianowska E. (2018). Attitudes of Young Consumers Towards Ecological Bakery and Confectionery Food Products - a Case Study (in Polish). Problems of World Agriculture, 18(2), 238-248; DOI: 10.22630/PRS.2018.18.2.51 